\title{
Relative stability of transgene DNA fragments from GM rapeseed in mixed ruminal cultures
}

\author{
Ranjana Sharma ${ }^{1}$, Trevor W. Alexander ${ }^{1,2}$, S. Jacob John ${ }^{3}$, Robert J. Forster ${ }^{1}$ and \\ Tim A. McAllister ${ }^{1 *}$ \\ ${ }^{1}$ Agriculture and Agri-Food Canada Research Center, P.O. Box 3000, Lethbridge, Alberta Canada T1J 4B1 \\ ${ }^{2}$ Department of Agricultural, Food and Nutritional Science, University of Alberta, Edmonton, Alberta, \\ Canada T6G 2P5 \\ ${ }^{3}$ Aquaculture Centre for Excellence, Lethbridge Community College, Lethbridge, Alberta, Canada T1K 1 L6
}

(Received 24 April 2003 - Revised 10 October 2003 - Accepted 15 January 2004)

\begin{abstract}
The use of transgenic crops as feeds for ruminant animals has prompted study of the possible uptake of transgene fragments by ruminal micro-organisms and/or intestinal absorption of fragments surviving passage through the rumen. The persistence in buffered ruminal contents of seven different recombinant DNA fragments from GM rapeseed expressing the 5-enolpyruvylshikimate-3-phosphate synthase $(E P S P S)$ transgene was tracked using PCR. Parental and transgenic (i.e. glyphosphate-tolerant; Roundup Ready ${ }^{\circledR}$, Monsanto Company, St Louis, MO, USA) rapeseed were incubated for $0,2,4,8,12,24$ and $48 \mathrm{~h}$ as whole seeds, cracked seeds, rapeseed meal, and as pelleted, barley-based diets containing $65 \mathrm{~g}$ rapeseed meal $/ \mathrm{kg}$. The seven transgene fragments ranged from 179 to $527 \mathrm{bp}$ and spanned the entire 1363 bp EPSPS transgene. A 180 bp ribulose-1,5-bisphosphate carboxylase/oxygenase (Rubisco) small subunit fragment and a $466 \mathrm{bp}$ 16S rDNA fragment were used as controls for endogenous rapeseed DNA and bacterial DNA respectively. The limit of detection of the PCR assay, established using negative controls spiked with known quantities of DNA, was 12.5 pg. Production of gas and $\mathrm{NH}_{3}$ was monitored throughout the incubation and confirmed active in vitro fermentation. Bacterial DNA was detected in all sample types at all time points. Persistence patterns of endogenous (Rubisco) and recombinant (EPSPS) rapeseed DNA were inversely related to substrate digestibility (amplifiable for 48,8 and $4 \mathrm{~h}$ in whole or cracked seeds, meal and diets respectively), but did not differ between parental and GM rapeseed, nor among fragments. Detection of fragments was representative of persistence of the whole transgene. No EPSPS fragments were amplifiable in microbial DNA, suggesting that transformation had not occurred during the $48 \mathrm{~h}$ incubation. Uptake of transgenic DNA fragments by ruminal bacteria is probably precluded or time-limited by rapid degradation of plant DNA upon plant cell lysis.
\end{abstract}

Genetically modified: EPSPS gene fragments: Roundup Ready ${ }^{\circledR}$ rapeseed: Rubisco: Foreign DNA stability

The agronomic improvements afforded by genetic modification of crops has resulted in a dramatic increase in their use in Canada, USA and Argentina (Kleter \& Kuiper, 2002). Approximately $55 \%$ of the $48600 \mathrm{~km}^{2}$ of rapeseed production in Canada were seeded to GM varieties in 2000 (Canola Council of Canada, 2001). In $2001,256 \times 10^{6} \mathrm{~kg}$ rapeseed meal were used in ruminant animal production in Canada (Statistics Canada, 2003). Thus, as adoption of GM crops continues to increase, so will their consumption by animals reared for food. However, despite rigorous approval standards for transgenic plants, little is known about the fate of recombinant DNA following ingestion of GM crops by animals and exposure of the plant DNA to micro-organisms within the digestive tract.
Ruminant animals harbour numerous bacteria, fungi and protozoa in their rumens and lower digestive tracts, and although these animals consume large amounts of plant material each day, most of the intact DNA present in their digesta is of microbial origin (Smith \& McAllan, 1970). It has been shown that naked DNA is rapidly degraded in ruminal contents (Duggan et al. 2000; Ruiz et al. 2000). From a study in which glyphosate-tolerant (Roundup Ready ${ }^{\circledR}$, Monsanto Company, St Louis, MO, USA) rapeseed seeds and meal were incubated in bovine ruminal contents, Alexander et al. (2002) concluded that any intact plant DNA found in the digesta was likely to be contained within intact plant cells, as plant DNA (endogenous or recombinant) was detected only in the feed particle fraction of the incubation medium. Similarly,

\footnotetext{
Abbreviations: CS, cracked seed; D, pelleted diet; EPSPS, 5-enolpyruvylshikimate-3-phosphate synthase; M, meal; P, parental rapeseed; R, Roundup Ready ${ }^{\circledR}$ rapeseed; Rubisco, ribulose-1,5-bisphosphate carboxylase/oxygenase; WS, whole seed.

* Corresponding author: Dr Tim A. McAllister, fax + 1403 3823156, email mcallister@agr.gc.ca
} 
in detecting ribulose-1,5-bisphosphate carboxylase/oxygenase (Rubisco) fragments in the spleen and liver of the soyabean-fed mice, Hohlweg \& Doerfler (2001) proposed that plant-associated DNA is more stable in the intestinal tract of mice than is naked DNA.

Rapid ruminal degradation of naked DNA would presumably reduce the potential for the absorption of genetic material across the intestinal wall. In the few studies in which ruminant animals were fed GM plant material, no full-length genes or large fragments of recombinant plant DNA were detected in animal tissues or products (Einspanier et al. 2001; Phipps et al. 2002). Einspanier et al. (2001) did, however, detect short fragments of endogenous plant DNA in the lymphocytes of cows fed GM maize. In addition, Duggan et al. (2003) recently reported detection of a $211 \mathrm{bp}$ amplicon from the cryIA(b) gene in ruminal contents $24 \mathrm{~h}$ after feeding GM maize grain to sheep.

Transformation of gut micro-organisms with recombinant DNA, or its absorption by animals consuming GM feeds may be size- or sequence-dependent. Given the abundance of nuclease activity in the rumen, it is likely that plant DNA released into that environment will be digested into a multitude of fragments of varying sizes, which may exhibit differential stability in the digesta. Presumably, fragments with the greatest stability would be more likely to be taken up by bacteria or to pass through the rumen to the lower digestive tract. The present study was conducted to investigate the persistence and possible differential stability in ruminal fluid of fragments of the CP4 5-enolpyruvylshikimate-3-phosphate synthase (EPSPS) transgene from Roundup Ready ${ }^{\circledR}$ rapeseed as whole seeds (WS) and cracked seeds (CS), and in formulations typical for use as animal feed.

\section{Materials and methods}

\section{Rapeseed substrates}

Roundup Ready ${ }^{\circledR}$ rapeseed and the parental line from which it was derived (denoted $\mathrm{R}$ and $\mathrm{P}$ respectively) were used in the in vitro incubation, each as whole seed (P-WS, R-WS), cracked seed (P-CS, R-CS), rapeseed meal (P-M, R-M) and a pelleted diet containing rapeseed meal (P-D, R-D). Rapeseed seed was obtained from Monsanto Company and rapeseed meal was prepared at Texas Engineering Experiment Station (Texas A\&M University, College Station, TX, USA) as described by Alexander et al. (2002). Rapeseed plants were grown in a phytotron facility at the Lethbridge Research Centre (Lethbridge, Alta., Canada) to provide leaf tissue for DNA controls. The barley grain-based pelleted diets (P-D and R-D) for lambs were also prepared at Lethbridge Research Centre; they contained $65 \mathrm{~g}$ rapeseed meal $(\mathrm{P}$ or $\mathrm{R}) / \mathrm{kg}$. A rolling pin was used to crack whole seeds to produce P-CS and R-CS. Rapeseed meals and diets were ground to pass through a $1 \mathrm{~mm}$ screen before use as substrates.

\section{In vitro incubation}

Inoculum for the in vitro incubation was prepared using ruminal contents from a cannulated Jersey steer maintained on fresh lucerne forage. At the barn, ruminal contents (approximately 2 litres) were strained through four layers of cheesecloth into a pre-warmed flask and the resulting solids were sealed into a plastic bag; both were transported immediately to the laboratory. Inoculum was prepared by processing 1.5 litres ruminal filtrate and $375 \mathrm{~g}$ solids in a blender (three $45 \mathrm{~s}$ pulses), straining the homogenate through four layers of cheesecloth, and combining the filtrate with 2 vols prewarmed, pre-gassed buffer (Menke et al. 1979).

The incubation was conducted as described by Alexander et al. (2002). Briefly, $20 \mathrm{ml}$ inoculum was added to $250 \mathrm{mg}$ rapeseed substrate that had been pre-weighed into $35 \mathrm{ml}$ serum vials. Triplicate vials of each substrate (P-WS, R-WS, P-CS, R-CS, P-M, R-M, P-D and R-D) were prepared for each of seven sampling times $(0,2,4,8,12,24$ and $48 \mathrm{~h}$ ). Vials were flushed with $\mathrm{CO}_{2}$ before and after addition of inoculum; then eighteen vials of each substrate were sealed, affixed to a rotary shaker and placed in an incubator at $39^{\circ} \mathrm{C}$. The $0 \mathrm{~h}$ vials were processed immediately upon addition of inoculum, as described later.

\section{Sample processing}

Triplicate vials of each substrate were removed from the incubation after $0,2,4,8,12,24$ and $48 \mathrm{~h}$. Progression of anaerobic fermentation in each vial was monitored by measuring gas production and accumulation of $\mathrm{NH}_{3}$. Headspace gas was measured by water displacement (Fedorak \& Hrudey, 1983) before opening the vials, then the contents were transferred to $50 \mathrm{ml}$ centrifuge tubes. Plant debris and particle-associated bacteria were sedimented by lowspeed centrifugation $\left(500 \mathrm{~g}, 10 \mathrm{~min}, 4^{\circ} \mathrm{C}\right)$. The supernatant fraction was decanted and the pellet (pellet A) was frozen immediately in liquid $\mathrm{N}_{2}$ for DNA isolation (see later). A $2 \mathrm{ml}$ portion of the supernatant fraction (fraction A) was set aside for determination of $\mathrm{NH}_{3}$ (Broderick \& Kang, 1980) and the remainder was immediately re-centrifuged $(10000 \mathrm{~g}, 10 \mathrm{~min}$, room temperature). The pellet (pellet B), which comprised primarily fluid-associated bacteria, was flash frozen in liquid $\mathrm{N}_{2}$ and the supernatant fraction (fraction B) was processed immediately for isolation of any free DNA as described later.

\section{Extraction of DNA}

Isolation of free DNA from fraction B was conducted using a QIAmp DNA Minikit (Qiagen Inc., Mississauga, Ont., Canada) and the manufacturer's protocol for body fluid samples. A modified CTAB extraction procedure (Alexander et al. 2002) was used for DNA extractions from pellet A (i.e. plant debris, particle-associated bacteria), as well as from non-incubated WS, CS, M and D. For isolation of DNA from pellet B (fluid-associated bacteria), the Wizard $^{\circledR}$ genomic DNA purification kit (Promega Ltd, Madison, WI, USA) was used.

Rapeseed plants ( $\mathrm{P}$ and $\mathrm{R}$ ) were grown in the phytotron facility at the Lethbridge Research Centre from seed of the same batch used for the in vitro incubation. Leaves from these plants were flash frozen in liquid $\mathrm{N}_{2}$ immediately upon harvest, and the DNeasy Plant Mini Kit 
(Qiagen Inc.) was used to extract DNA for inclusion as positive controls in PCR.

\section{PCR analyses}

Primer sets were designed to amplify seven different regions spanning the recombinant construct encoding EPSPS (Fig. 1). Forward primer PF2 (5'-AAG GCA TTC ATT CCC ATT TG-3') and reverse primer ER3 (5'-ATT GCA GAT TCT GCT AAC TTG- $3^{\prime}$ ) amplified a 179 bp fragment $\left(\mathrm{F}_{1}\right)$ located in the promoter/CTP region of the construct; forward primer PF2 and reverse primer ER1 (5'-TAA CAT CTT CAC CTT CCA AAA G-3') amplified a 527 bp fragment $\left(\mathrm{F}_{2}\right)$ in the promoter/EPSPS region; forward primer EF6 (5'-GAC GCA GCA GCA TCC AC-3') and reverse primer ER1 amplified a $300 \mathrm{bp}$ fragment $\left(\mathrm{F}_{3}\right)$ in the CTP/EPSPS region; forward primer EF4 (5'-CAA CAC TGG TAA GGC TAT GC- $3^{\prime}$ ) and reverse primer ER4 (5'-GGT AAC TGG AAG ACG ATC AC-3') amplified a $300 \mathrm{bp}$ fragment $\left(\mathrm{F}_{4}\right)$ from the EPSPS region; forward primer EF5 (5'-CGT GGC TGA CTT GCG TG-3') and reverse primer ER5 (5'-CGT TAC CGA GAC CCT TAC C-3 $3^{\prime}$ ) amplified a $278 \mathrm{bp}$ fragment $\left(\mathrm{F}_{5}\right)$ from EPSPS; forward primer EF2 (5'-TTG ATT GCG ATG AAG GTG AG- $\left.3^{\prime}\right)$ and reverse primer TR (5'-ACA AAT GGT ACA AGA AAA ACA G-3 $\left.{ }^{\prime}\right)$ amplified a 420 bp fragment $\left(\mathrm{F}_{6}\right)$ in the EPSPS/terminator region; forward primer EF2 and reverse primer ER2 (5'-TCA AGC AGC CTT AGT GTC G-3') amplified a $270 \mathrm{bp}$ fragment $\left(\mathrm{F}_{7}\right)$ in the $3^{\prime}$ EPSPS region. Conditions of PCR used for detection of the transgene fragments were the same for each of the primer pairs: $95^{\circ} \mathrm{C}$ for $5 \mathrm{~min}$, followed by thirty-five cycles of $94^{\circ} \mathrm{C}$ for $1 \mathrm{~min}, 58^{\circ} \mathrm{C}$ for $30 \mathrm{~s}, 72^{\circ} \mathrm{C}$ for $1 \mathrm{~min}$, and a final extension at $72^{\circ} \mathrm{C}$ for $10 \mathrm{~min}$.

A $180 \mathrm{bp}$ fragment of the gene encoding the Brassica napus Rubisco small subunit was used as a control for detecting endogenous rapeseed DNA (GenBank accession no. $\mathrm{X} 75334)$. It was detected using the forward primer $R b c \mathrm{~F} 1$ (5'-CAC ATA TCC ATG CGA TGC G- $3^{\prime}$ ) and reverse primer $R b c$ R1 ( $5^{\prime}$-ACC CAA AGA TAA AGG TAG CC$\left.3^{\prime}\right)$. Conditions of PCR for amplification of the Rubisco fragment were: $95^{\circ} \mathrm{C}$ for $5 \mathrm{~min}$, thirty cycles of $94^{\circ} \mathrm{C}$ for $1 \mathrm{~min}$, $62^{\circ} \mathrm{C}$ for $30 \mathrm{~s}, 72^{\circ} \mathrm{C}$ for $1 \mathrm{~min}$, and a final extension at $72^{\circ} \mathrm{C}$ for $10 \mathrm{~min}$. Universal primers were used to detect bacterial DNA encoding 16S rDNA (Nadkarni et al. 2002) at each sampling time. Forward primer BF $\left(5^{\prime}-\right.$ TCC TAC GGG
AGG CAG CAG $\left.\mathrm{T}-3^{\prime}\right)$ and reverse primer BR (5'-GGA CTA CCA GGG TAT CTA ATC CTG TT-3') were used to amplify $466 \mathrm{bp}$ fragment with thermocycling conditions of $95^{\circ} \mathrm{C}$ for $10 \mathrm{~min}$, twenty-two cycles of $95^{\circ} \mathrm{C}$ for $15 \mathrm{~s}$, $68.5^{\circ} \mathrm{C}$ for $30 \mathrm{~s}$, and $72^{\circ} \mathrm{C}$ for $30 \mathrm{~s}$, followed by $72^{\circ} \mathrm{C}$ for $10 \mathrm{~min}$ (Alexander et al. 2002).

All PCR mixtures $(50 \mu \mathrm{l})$ contained the following (final concentrations): $1 \times$ PCR buffer, $0.2 \mathrm{mM}$-dNTP mix, $0.5 \mu \mathrm{M}$ each of forward and reverse primer, $1.5 \mathrm{mM}$ $\mathrm{MgCl}_{2}$ and $2.5 \mathrm{U}$ Taq Polymerase (Invitrogen, Burlington, Ont., Canada). For DNA isolated from plant (seed, meal, diet; pellet from slow-speed centrifugation) or bacterial (Escherichia coli control; pellet from high-speed centrifugation) materials, $100 \mathrm{ng}$ DNA template was used in the PCR. However, the concentration of DNA isolated from the supernatant fraction was $<100 \mathrm{ng} / \mu \mathrm{l}$; therefore, $5 \mu \mathrm{l}$ DNA solution was used as a template for PCR amplification. All PCR were performed on a PTC 100 thermocycler (M.J. Research Inc., Watertown, MA, USA). Each PCR setup included a negative control (containing no template DNA), as well as appropriate positive controls (parental and/or transgenic rapeseed leaf DNA as plant controls, and/or E. coli DNA as a bacterial control) as indicated. In all cases, $20 \mu \mathrm{l}$ PCR product were resolved on agarose $(15 \mathrm{~g} / \mathrm{l})$ gels containing ethidium bromide, using standard procedures (Sambrook et al. 1989).

\section{Confirmation of limits of detection}

Limit of detection assays were conducted to determine the sensitivity of the PCR for each of the primer sets designed to amplify the EPSPS transgene fragments. Purified Roundup Ready ${ }^{\circledR}$ rapeseed meal DNA was included in the $50 \mu \mathrm{l} \mathrm{PCR}$ mixtures in quantities of $1000 \cdot 00,500 \cdot 00$, $200 \cdot 00,100 \cdot 00,50 \cdot 00,25 \cdot 00,12.50,6.25$ and $0.00 \mathrm{pg}$. Matrix DNA isolated from the plant debris (pellet A) from the $8 \mathrm{~h}$ parental diet incubation was included in each PCR (100 ng) as a control for template DNA. Other PCR mixture components, thermocycling conditions and resolution of PCR products were identical to those described earlier.

\section{Statistical analyses}

$\mathrm{NH}_{3}$ and gas production data were analysed by ANOVA (version 8.1, 1999; SAS Institute Inc., Cary, NC, USA).

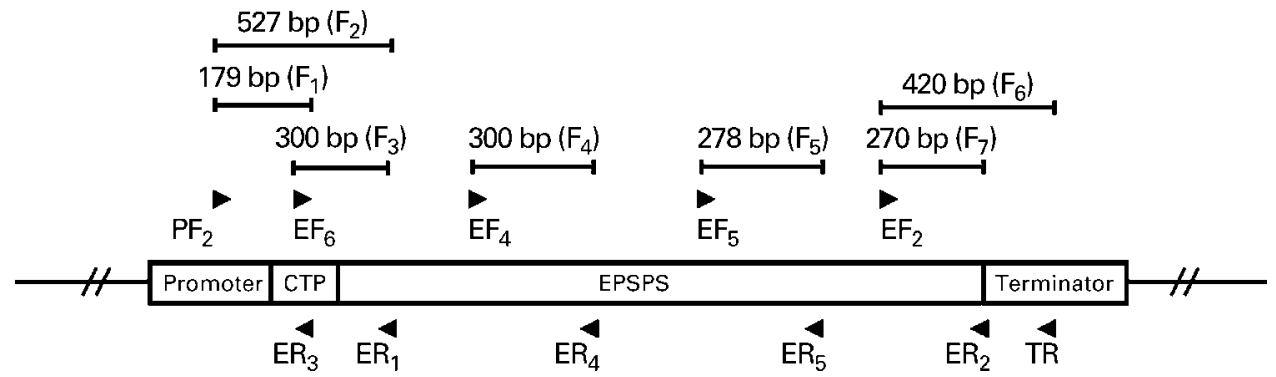

Fig. 1. Schematic representation of the CP4 5-enolpyruvylshikimate-3-phosphate synthase (EPSPS) construct showing locations of the designed primers and the respective fragments amplified $\left(F_{1}\right.$ to $\left.F_{7}\right)$. Drawing not to scale. 
Treatment effects were compared using the procedures LS MEANS with PDIFF.

\section{Results and discussion}

\section{Substrate digestion}

Accumulations of gas and $\mathrm{NH}_{3}$ measured in the incubation vials over the $48 \mathrm{~h}$ incubation period (Fig. 2) were indicative of active ruminal fermentation and consistent with other reported findings for similar incubations (Wang et al. 1997). As expected, these variables differed among substrate types (WS, CS, M and D). Gas production at $48 \mathrm{~h}$ was strongly linked to the degree to which the substrates had been physically processed $(\mathrm{D}>\mathrm{M}>\mathrm{CS}>\mathrm{WS}$; $P<0.01)$; this reflects enhanced availability of digestible internal components of the rapeseed seed (and barley grain, in the case of P-D and R-D) to microbial colonization and degradation (Wang et al. 1997). $\mathrm{NH}_{3}$ concentrations at
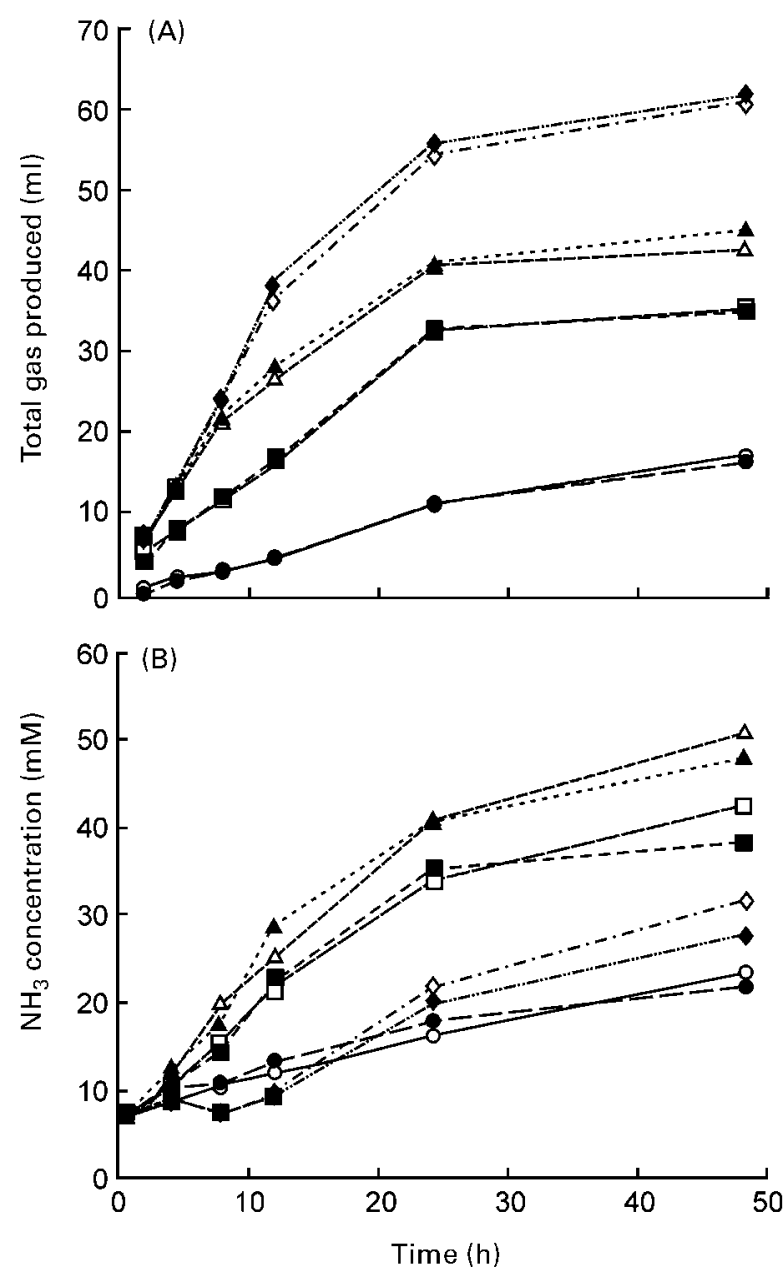

Fig. 2. Total gas production $(A)$ and accumulation of ammonia (B) during a $48 \mathrm{~h}$ incubation of parental $(\mathrm{P})$ and Roundup Ready ${ }^{\circledR}$ (R; Monsanto Company, St Louis, MO, USA) rapeseed in buffered ruminal contents. The rapeseed was incubated as whole seeds $(\mathrm{O}, \mathrm{P}$; ө, R), cracked seeds $(\square, \mathrm{P} ; \boldsymbol{\square}, \mathrm{R})$, meal $(\triangle, \mathrm{P}$; $\Delta, \mathrm{R})$ and pelleted meal-containing diets $(\diamond, P, \diamond, \mathrm{R})$. Values are the means of triplicate determinations. For details of procedures, see p. 674.
$48 \mathrm{~h}$ were also related to the degree of processing of the rapeseed, but the effect was less pronounced $(\mathrm{M}>\mathrm{CS}>\mathrm{WS}$ and $\mathrm{D} ; P<0 \cdot 10)$, because they arise as the balance of microbial amino acid deamination and microbial $\mathrm{NH}_{3}$ uptake (Wallace et al. 1997). The relatively low $\mathrm{NH}_{3}$ concentrations measured during incubation of diets (similar to WS; $P>0 \cdot 10$ ) is likely to be because of the lower crude protein $(\mathrm{N} \times 6.25)$ content in the diets as compared with rapeseed seed and meal.

Gas production and $\mathrm{NH}_{3}$ accumulation differed predictably among substrate types, but they were similar $(P>0.05)$ between $\mathrm{P}$ and $\mathrm{R}$ rapeseed. This suggests that the presence of the EPSPS transgene did not affect ruminal degradation of the rapeseed, i.e. that $\mathrm{P}$ and $\mathrm{R}$ were responding similarly to microbial digestive attack. The concept of substantial equivalence between a parental line of feed and its recombinant counterpart is a key feature in the acceptance of GM feeds (Organization of Economic Cooperation \& Development, 1993; Martens, 2000).

\section{Detection of endogenous and recombinant rapeseed DNA}

Endogenous rapeseed DNA (represented by the $180 \mathrm{bp}$ Rubisco fragment) was readily detectable in the pelleted plant debris (pellet A). The duration of its persistence was related to the physical condition of the substrates, but no differences were evident between P and R (Fig. 3). The Rubisco fragment was detectable at all time points in incubations of P-WS, R-WS, P-CS and R-CS (results for 24 and $48 \mathrm{~h}$ not shown), but only at $0,2,4$, and $8 \mathrm{~h}$ from meal (P-M and R-M) and not beyond $4 \mathrm{~h}$ in diet (P-D and R-D).

Persistence of CP4 EPSPS fragments during the in vitro incubation mirrored that of the endogenous $180 \mathrm{bp}$ Rubisco fragment. Each of the seven fragments in DNA isolated from WS or CS was detectable at $48 \mathrm{~h}$ (Fig. 4), whereas from $\mathrm{M}$ and $\mathrm{D}$, except $\mathrm{F}_{2}$ detectable in $\mathrm{M}$ at $12 \mathrm{~h}$, the fragments were not observed beyond 8 and $4 \mathrm{~h}$ respectively (Fig. 5). The limit of detection of the PCR assay was established at $12.5 \mathrm{pg}$ (representative results presented in Fig. 6). As with endogenous rapeseed DNA and the complete $1363 \mathrm{bp}$ transgene (Alexander et al. 2002), decline of CP4 EPSPS fragment concentrations below detectable limits by $8 \mathrm{~h}$ in incubations of meal-containing diet (R-D) compared with $12 \mathrm{~h}$ in incubations of meal (R-M) is attributed to lower initial concentration of rapeseed DNA in the diet $(65 \mathrm{~g}$ rapeseed/ $\mathrm{kg}$ ) than in the meal itself. Observation of a faint $F_{2}$ band at $12 \mathrm{~h}$ in R-M was surprising, given that neither $F_{1}$ nor $F_{3}$, both of which fall within $F_{2}$, were detected beyond $8 \mathrm{~h}$. It may be that $\mathrm{F}_{2}$ was present at a concentration near the limit of detection, and by chance alone, was detected at $12 \mathrm{~h}$.

Patterns of persistence of endogenous (Rubisco) and transgene (EPSPS) DNA among WS, CS and M were consistent with the determinations of in vitro digestibility (measured as accumulation of gas and $\mathrm{NH}_{3}$; Fig. 2). As digestibility of the rapeseed preparation increased, the duration of persistence of DNA in the plant debris pellet decreased. No differences were observed between endogenous parental and Roundup Ready ${ }^{\circledR}$ rapeseed 


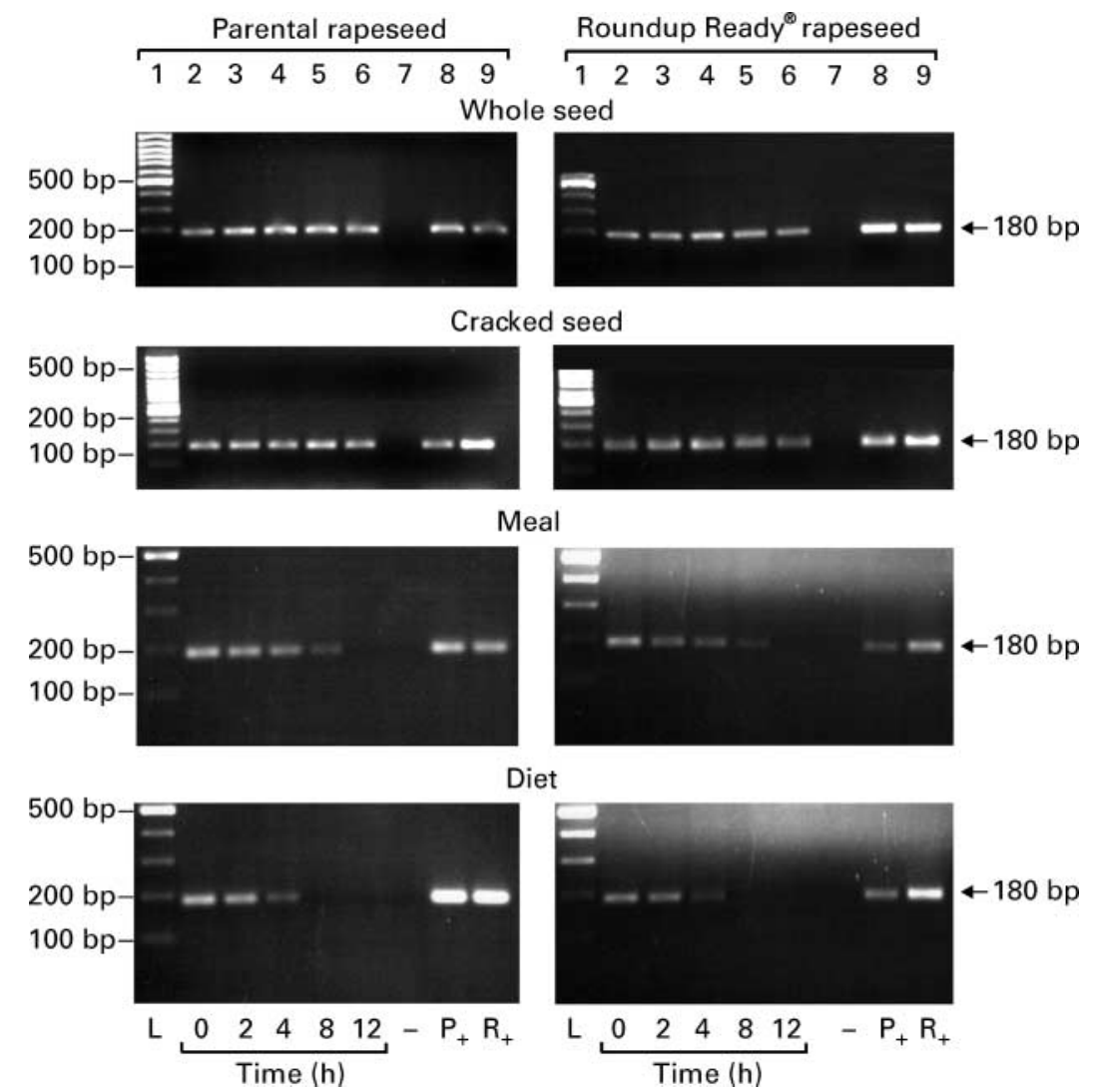

Fig. 3. Detection of endogenous rapeseed DNA (as a $180 \mathrm{bp}$ rapeseed-specific Rubisco fragment) in sedimented plant debris from the first $12 \mathrm{~h}$ of incubation of whole and processed parental and Roundup Ready ${ }^{\circledR}$ (Monsanto Company, St Louis, MO, USA) rapeseed in buffered ruminal contents. Lane 1, 100 bp DNA Ladder Plus (L); lanes 2 to 6 , DNA isolated from samples collected after 0, 2, 4, 8 and $12 \mathrm{~h}$ of incubation; lane 7, negative control (no DNA template); lanes 8 and 9, positive controls (DNA isolated from leaves of parental $\left(P_{+}\right)$and Roundup Ready ${ }^{\circledR}\left(R_{+}\right)$rapeseed grown from the whole seed). For details of procedures, see p. 674.

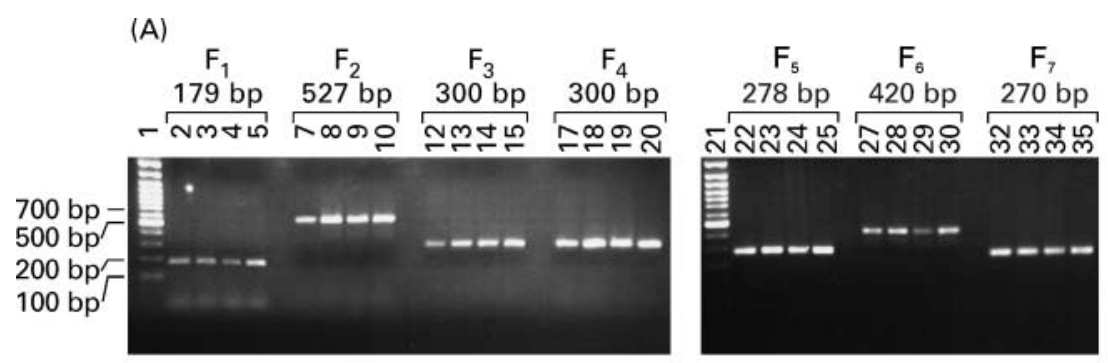

(B)

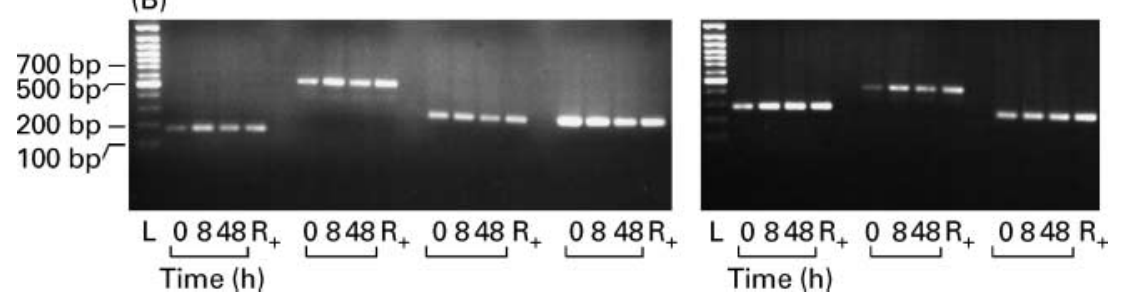

Fig. 4. Detection of seven different CP4 5-enolpyruvylshikimate-3-phosphate synthase (EPSPS) fragments spanning the transgene construct (see Fig. 1) in DNA isolated from sedimented plant debris from a $48 \mathrm{~h}$ incubation of (A) whole and (B) cracked Roundup Ready ${ }^{\circledR}$ rapeseed (Monsanto Company, St Louis, MO, USA) in buffered ruminal contents. Lanes 1 and 21, 100 bp DNA Ladder Plus (L); lanes 2 to 20 and 22 to 35 , four-lane sets pertaining to each of the seven fragments $\left(F_{1}\right.$ to $\left.F_{7}\right)$. They contain (left to right) DNA from samples collected after 0,8 and $48 \mathrm{~h}$ of incubation, plus a positive control $\left(R_{+}\right)$, which is DNA isolated from leaves of Roundup Ready ${ }^{\circledR}$ rapeseed grown from the whole seed. Lanes $6,11,16,26$ and 31 are empty. For details of procedures, see p. 674. 

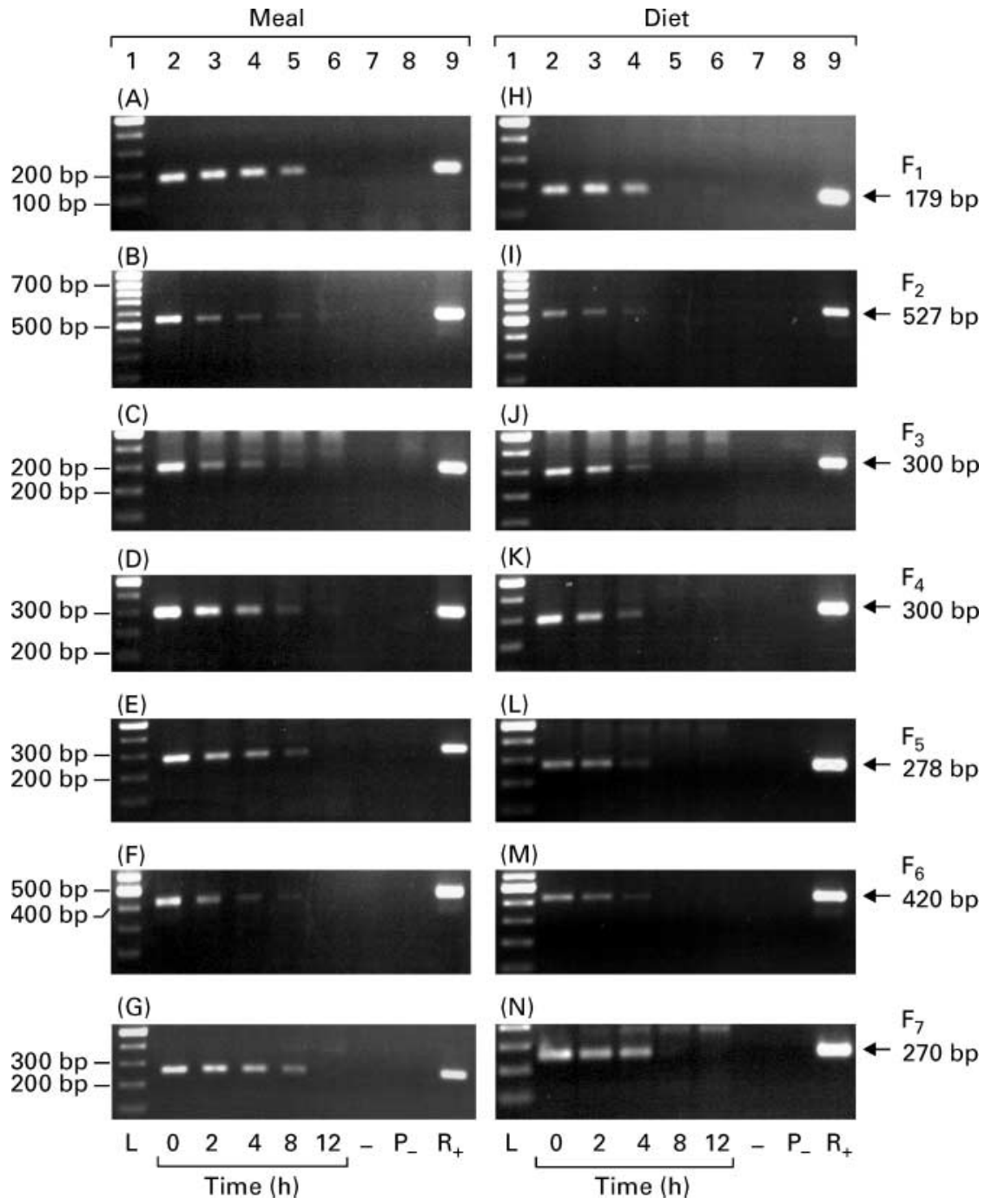

Fig. 5. Detection of seven different CP4 5-enolpyruvylshikimate-3-phosphate synthase (EPSPS) fragments (see Fig. 1) in sedimented plant debris from the first $12 \mathrm{~h}$ of incubation of meal $((A),(B),(C),(D),(E),(F)$ and $(G))$ and pelleted diet $((H),(I),(J),(K),(L),(M)$ and (N)) prepared from Roundup Ready ${ }^{\circledR}$ rapeseed (Monsanto Company, St Louis, MO, USA). Lane 1, 100 bp DNA Ladder Plus (L); lanes 2 to 6, DNA from samples collected after $0,2,4,8$ and 12 of incubation; lane 7, negative control (no DNA template); lanes 8 and 9, negative and positive controls (DNA isolated from leaves of parental $\left(P_{-}\right)$and Roundup Ready ${ }^{\circledR}\left(R_{+}\right)$rapeseed grown from seed). For details of procedures, see p. 674 .

DNA (Rubisco fragment), nor among the seven EPSPS fragments in the recombinant rapeseed. In addition, relative persistence of the EPSPS fragments in WS, CS and M was consistent with observations made on the complete EPSPS transgene (Alexander et al. 2002). These observations suggest that endogenous and recombinant Roundup Ready ${ }^{\circledR}$ rapeseed are substantially equivalent in terms of degradation of DNA during ruminal incubation, and that susceptibility of the transgene to degradation is essentially uniform along its length. Einspanier et al. (2001) attributed detection of a 199 bp large subunit Rubisco fragment in tissues of forage-fed cattle to high copy number of the endogenous DNA (as compared with a recombinant gene, which was not detected). The present findings support that conclusion, rather than a differential persistence of the 199 bp Rubisco fragment in the digesta.
Plant debris was evident (as pellet A) throughout the $48 \mathrm{~h}$ incubation of meals and diets, yet the recombinant gene fragments were not detectable beyond 8 or $4 \mathrm{~h}$, which is consistent with our earlier conclusion that DNA in breached plant cells is rapidly degraded by nucleases present in ruminal contents (Alexander et al. 2002). McAllan \& Smith (1973) reported similar degradation of plant cellular structures during in vitro ruminal incubation, evidenced as increasing concentrations of mono- and oligonucleotides in cell-free extracts from a $6 \mathrm{~h}$ incubation of lucerne hay in ruminal contents. That study did not distinguish between plant and bacterial DNA; thus, it is possible that the increase in DNA may have been due to bacterial proliferation and lysis.

As expected, bacterial DNA (as the $466 \mathrm{bp} 16 \mathrm{~S}$ rDNA fragment) was detectable over the entire $48 \mathrm{~h}$ incubation 

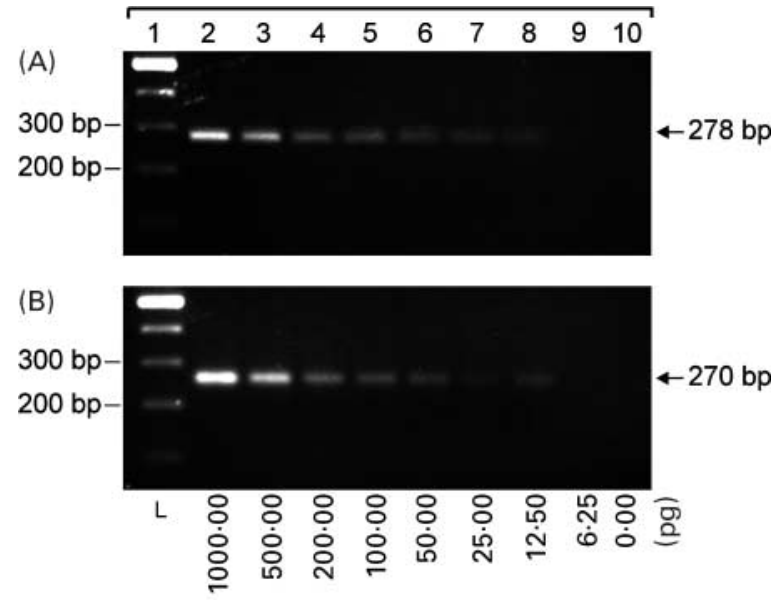

Fig. 6. Demonstration of sensitivity of the PCR assay for detecting CP4 5-enolpyruvylshikimate-3-phosphate synthase (EPSPS) fragments. PCR mixtures (containing $100 \mathrm{ng}$ DNA from $8 \mathrm{~h}$ parental meal pellet $A$ as a control for template DNA) were spiked with known quantities of DNA purified from Roundup Ready ${ }^{\circledR}$ rapeseed (Monsanto Company, St Louis, MO, USA) meal (R-M). Assays were conducted with all seven primer sets. Representative results $\left(F_{5}\right.$ in $(A) ; F_{7}$ in $\left.(B)\right)$ are shown. Lane $1,100 \mathrm{bp}$ DNA Ladder Plus (L); lanes 2 to 10, PCR mixtures containing $1000.00,500.00,200.00,100.00,50.00,25.00,12.50,6.25$ or $0.00 \mathrm{pg}$ purified DNA from R-M. For details of procedures, see p. 674 .

in pellet $\mathrm{B}$ (sedimented fluid-associated bacteria) from all eight substrates, whereas no rapeseed DNA was found (results not shown). Bacterial DNA was also detected in all preparations of pellet A (which included feed particleassociated bacteria), although as discussed earlier, rapeseed DNA was only amplifiable for up to $8 \mathrm{~h}$. In fraction $\mathrm{B}$, bacterial DNA was detected consistently (Fig. 7(A)), whereas endogenous (Rubisco) and recombinant (EPSPS) rapeseed DNA were not (Fig. 7(B), (C), (D), (E) and (F)). To determine whether or not PCR inhibitors may have been present in the supernatant fraction and limiting transgene detection, the PCR was repeated with a subset of mixtures randomly spiked with $50 \mathrm{ng}$ DNA isolated from Roundup Ready ${ }^{\circledR}$ rapeseed leaf. In all cases, Rubisco and EPSPS sequences were readily amplified, confirming their true absence in the supernatant fraction.

The genes studied here are low or single copy, with Rubisco being nuclear encoded, and the EPSPS construct being present at one copy per cell (Health Canada, 1999), which may explain why no plant DNA was detected in the supernatant fraction after incubation. Another possibility is that upon lysis of plant cells in the ruminal environment, the DNA released is almost immediately degraded to sizes smaller than investigated here (less than $179 \mathrm{bp}$ ). Duggan et al. (2000) reported that a $350 \mathrm{bp}$ recombinant gene sequence from maize chromosomal DNA could not be amplified beyond the first minute of incubation in ovine ruminal contents. Detection of bacterial DNA in fraction $B$ in the present study may be due to the high initial concentration of bacteria, such that even at an equally rapid rate of DNA degradation, the abundant template enabled its detection.
Knowing whether or not ruminal bacteria are capable of natural transformation and integration of recombinant plant DNA within the time frame $(4-8 \mathrm{~h})$ during which they could be exposed to the recombinant rapeseed DNA is of interest, given that bacterial DNA was detected consistently in all fractions of ruminal contents. Transfer of DNA to ruminal bacteria by transformation, conjugation and transduction under laboratory conditions has been documented (Morrison, 1996). In addition, although information on DNA exchange within the in vivo ruminal environment is lacking, there is some evidence that such processes have occurred across species (Nikolich et al. 1994; Garcia-Vallve et al. 2000).

The loss of biological activity of plasmid DNA within 1 min of incubation in ruminal fluid (Duggan et al. 2000) suggests that duration of exposure of the DNA is probably a major constraint to such a transformation event occurring in rumen bacteria. Transformation of fluid-associated bacteria is unlikely in light of the short half-life of free DNA in ruminal contents, but the close proximity to plant material of the feed particle-associated bacteria, which accounts for 70 to $80 \%$ of microbial matter in the rumen (McAllister et al. 1994), would increase the likelihood of their contacting plant DNA upon cellular degradation. A portion of these bacteria, formerly feed particle-associated, may be detected as fluid-associated following their release to the fluid milieu upon structural degradation of plant fragments (Cheng \& McAllister, 1997). Had transformation by the recombinant DNA occurred, however, one or more of the EPSPS fragments ought to have been amplifiable either from pellet $\mathrm{A}$ at time points beyond which Rubisco was no longer detectable, or from the bacterial preparations (pellet $\mathrm{B}$, fraction $\mathrm{B}$ ).

Intact plant material rather than naked DNA was used in the in vitro incubations to mimic the animal feeding scenario, and has revealed uniformity of stability along the $C P 4$ EPSPS transgene and no differences in ruminal stability between endogenous and recombinant plant DNA. This finding suggests that all of the primer sets examined in the present study should work equally well for detecting the presence of the EPSPS gene in a variety of matrices. On the basis of observations from the present study, future research will focus on culture and PCR analysis of feed particle-associated bacteria from early stage in vivo incubations (i.e. within $4 \mathrm{~h}$ of feeding GM rapeseed to livestock), i.e. the conditions most favourable for a transformation event to occur.

\section{Acknowledgements}

This research was conducted with financial support from the Canadian Food Inspection Agency, and from the Alberta Agricultural Research Institute and the Alberta Livestock Industry Development Fund (joint project no. 2002L053). A scholarship from the Natural Sciences and Engineering Research Council to R. S. is gratefully acknowledged. We thank Zhong Jun $\mathrm{Xu}$ for $\mathrm{NH}_{3}$ analysis, Dana Damgaard for technical support, Katherine Jakober for assistance with the manuscript and Bob Williams for help in various ways and sharing numerous articles. 

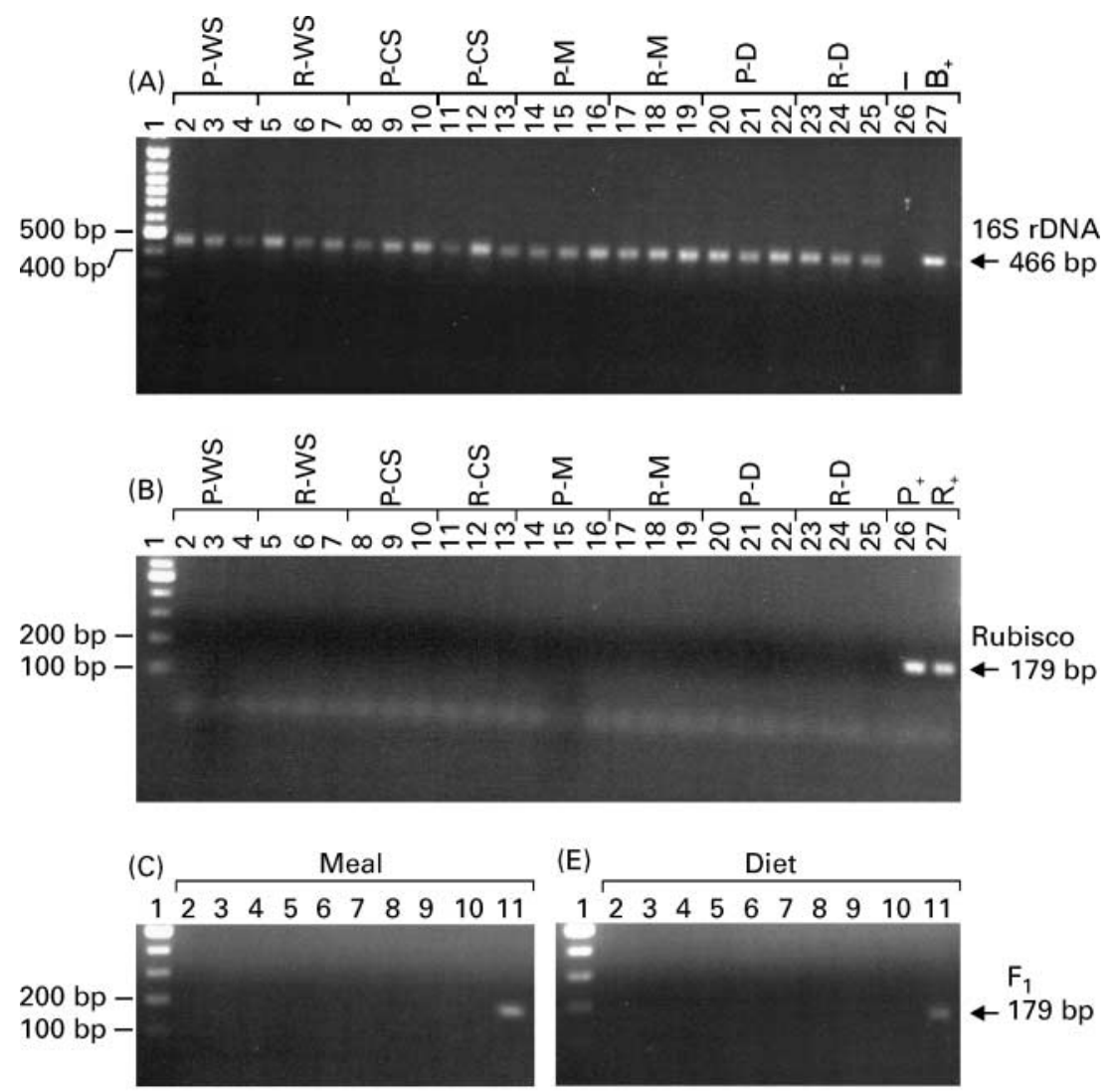

(D)

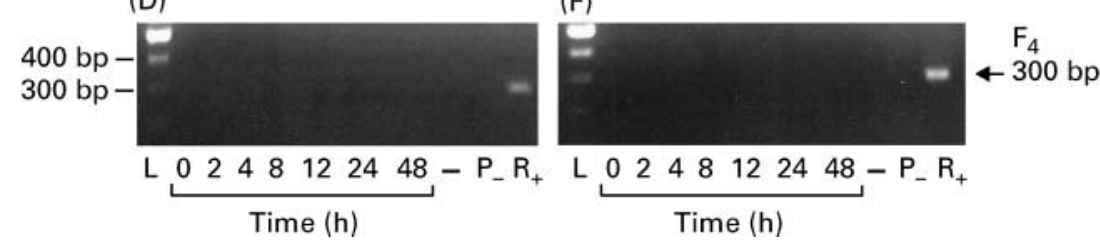

Fig. 7. Detection of bacterial DNA as a $466 \mathrm{bp}$ fragment of $16 \mathrm{~S}$ rDNA (A), endogenous rapeseed DNA as a 180 bp rapeseed-specific Rubisco fragment $(\mathrm{B})$, and CP4 5-enolpyruvylshikimate-3-phosphate synthase (EPSPS) DNA ( $\mathrm{F}_{1}$ and $\mathrm{F}_{4}$ as representative results; meal (C) and (D), $\operatorname{diet}(E)$ and $(F)$ ) in supernatant fraction B from $48 \mathrm{~h}$ in vitro incubations of parental $(P)$ and Roundup Ready ${ }^{\circledR}(R ;$ Monsanto Company, St Louis, $M O$, USA) rapeseed in buffered ruminal contents. Each rapeseed line ( $P$ and $R)$ was incubated as whole seeds ( $P$-WS, R-WS), cracked seeds (P-CS, R-CS), meal (P-M, R-M) or pelleted diet (P-D, R-D) made with rapeseed meal. In (A) and (B), lane 1, 100 bp DNA Ladder Plus (L); lanes 2 to 25: three-lane sets pertaining to each of the eight substrates, containing (left to right) DNA from samples collected after 0,8 and $48 \mathrm{~h}$ of incubation; lane 26, negative control (no DNA template); lane 27, positive control (466 bp fragment amplified from $E$. coll). In (C), (D), (E) and (F), lane 1, 100 bp DNA Ladder Plus (L); lanes 2 to 8, DNA from samples collected after 0, 2, 4, 8, 12, 24, and 48 h of incubation; lane 9 , negative control (no DNA template); lanes 10 and 11, DNA from leaves of parental and Roundup Ready ${ }^{\circledR}$ rapeseed, serving as negative ( $\left.P_{-}\right)$and positive $\left(\mathrm{R}_{+}\right)$controls for CP4 EPSPS. Rubisco, ribulose-1,5-bisphosphate carboxylase/oxygenase small subunit fragment. For details of procedures, see p. 674

We thank the Monsanto for provision of the parental and Roundup Ready ${ }^{\circledR}$ seeds, meal and recombinant gene sequences. This is Lethbridge Research Centre contribution number 38702113.

\section{References}

Alexander TW, Sharma R, Okine EK, Dixon WT, Forster RJ, Stanford K \& McAllister TA (2002) Impact of feed processing and mixed ruminal culture on the fate of recombinant EPSP synthase and endogenous canola plant DNA. FEMS Microbiol Lett 214, 263-269.

Broderick GA \& Kang JH (1980) Automated simultaneous determination of ammonia and total amino acids in ruminal fluid and in vitro media. J Dairy Sci 63, 64-75.
Canola Council of Canada (2001), Impact of Transgenic Canola on Growers, Industry and Environment. www.canola-council. org/manual/GMO/gmo_main.htm

Cheng K-JJ \& McAllister TA (1997) Compartmentation in the rumen. In The Rumen Microbial Ecosystem, 2nd ed. pp. 492-522 [PN Hobson and CS Stewart, editors]. London: Blackie Academic and Professional.

Duggan PS, Chambers PA, Heritage J \& Forbes JM (2000) Survival of free DNA encoding antibiotic resistance from transgenic maize and the transformation activity of DNA in ovine saliva, ovine rumen fluid and silage effluent. FEMS Microbiol Lett 191, 71-77.

Duggan PS, Chambers PA, Heritage J \& Forbes JM (2003) Fate of genetically modified maize DNA in the oral cavity and rumen of sheep. Br J Nutr 89, 159-166. 
Einspanier R, Klotz A, Kraft J, Aulrich K, Poser R, Schwagele F, Jahreis G \& Flachowsky G (2001) The fate of forage plant DNA in farm animals: a collaborative case-study investigating cattle and chicken fed recombinant plant material. Eur Food Res Technol 212, 129-134.

Fedorak PM \& Hrudey SE (1983) A simple apparatus for measuring gas production by methanogenic cultures in serum bottles. Environ Technol Lett 4, 425-432.

Garcia-Vallve S, Romeu A \& Palau J (2000) Horizontal gene transfer of glycosyl hydrolases of the rumen fungi. Mol Biol Evol 17, 352-361.

Health Canada (1999) Novel Food Information - Food Biotechnology. Glyphosate Tolerant Canola, GT200. http://www. hc-sc.gc.ca/food-aliment/mh-dm/ofb-bba/nfi-ani/ e_ofb-097-325-a.html

Hohlweg U \& Doerfler W (2001) On the fate of plant or other foreign genes upon the uptake in food or after intramuscular injection in mice. Mol Genet Genomics 265, 225-233.

Kleter GA \& Kuiper HA (2002) Considerations for the assessment of the safety of genetically modified animals used for human food or animal feed. Livest Prod Sci 74, 275-285.

McAllan AB \& Smith RH (1973) Degradation of nucleic acids in the rumen. Br J Nutr 29, 331-345.

McAllister TA, Bae HD, Jones GA \& Cheng K-J (1994) Microbial attachment and feed digestion in the rumen. $J$ Anim Sci 72, 3004-3018.

Martens MA (2000) Safety evaluation of genetically modified foods. Int Arch Occup Environ Health 73, Suppl. 1, S14-S18.

Menke KH, Raab L, Salewski A, Steinglass H, Fritz D \& Schneider W (1979) The estimation of the digestibility and metabolizable energy content of ruminant feeding stuffs from the gas production when they are incubated with ruminal culture on the fate of recombinant EPSP synthase and endogenous canola plant DNA. FEMS Microbiol Lett 214, 222-263.

Morrison M (1996) Do ruminal bacteria exchange genetic material? J Dairy Sci 79, 1476-1486.

Nadkarni MA, Martin FE, Jacques NA \& Hunter N (2002)
Determination of bacterial load by real-time PCR using a broad range (universal) probe and primer set. Microbiol SGM 148, 257-266.

Nikolich MP, Hong G, Shoemaker NB \& Salyers AA (1994) Evidence for natural horizontal transfer of tet $Q$ between bacteria that normally colonize humans and bacteria that normally colonize livestock. Appl Environ Microbiol 60, $3255-3260$.

Organization of Economic Cooperation and Development (1993) Food safety and biotechnology: concepts and principles. In Safety Evaluation of Foods Derived by Modern Biotechnology: Concepts and Principles, pp. 10-13 [Environment Directorate, OECD, editors]. Paris: OECD, http://www.oecd.org/dataoecd/ 57/3/1946129.pdf.

Phipps RH, Beever DE \& Humphries DJ (2002) Detection of transgenic DNA in milk from cows receiving herbicide tolerant (CP4EPSPS) soyabean meal. Livest Prod Sci 74, 269-273.

Ruiz TR, Andres S \& Smith GB (2000) Identification and characterization of nuclease activities in anaerobic environmental samples. Can J Microbiol 46, 736-740.

Sambrook J, Fritsch EF \& Maniatis T (1989) Gel electrophoresis of DNA. In Molecular Cloning: A Laboratory Manual, 2nd ed. pp. 6.9-6.13 [N Ford and C Nolan, editors]. Cold Spring Harbor, NY: Cold Spring Harbor Laboratory 1.

Smith RH \& McAllan AB (1970) Nucleic acid metabolism in the ruminant. Br J Nutr 24, 545-556.

Statistics Canada (2003), Livestock Feed Requirements Study. Canada and Provinces 1999, 2000, 2001. Catalogue no. 23501-XIE. Ottawa, Canada: Statistics Canada.

Wallace RJ, Onodera R \& Cotta MA (1997) Metabolism of nitrogen-containing compounds. In The Rumen Microbial Ecosystem, pp. 283-328 [PN Hobson and CS Stewart, editors]. New York: Blackie Academic \& Professional.

Wang Y, McAllister TA, Zobell DR, Pickard MD, Rode LM, Mir Z \& Cheng K-J (1997) The effect of micronization of full-fat canola seed on digestion in the rumen and total tract of dairy cows. Can J Anim Sci 77, 431-440. 